\title{
The effect of entrepreneurial orientation, use of information technology, and innovation capability on SMEs' competitive advantage and performance: evidence from Indonesia
}

\author{
Shabrina Widyanti ${ }^{1}$ and M Mahfudz² \\ 1,2Department of Management, Faculty of Economics and Business, Universitas Diponegoro, Indonesia
}

\begin{abstract}
The purpose of this paper is to analyze the effect of entrepreneurial orientation, the use of information technology, and the capability of innovation on competitive advantage and performance of SMEs through competitive advantage. In this research, the sample was 125 SMEs joined in the digital class "X" in Semarang City. The result of the analysis using SEM shows that entrepreneurial orientation positively affects performance and competitive advantage of SMEs. Innovation capabilities also have a positive effect on SMEs' competitive advantage and performance. The result also suggested that use of information technology has a positive effect on the competitive advantage and competitive advantage has a positive effect on the business performance of SMEs
\end{abstract} competitive advantage; performance; SMEs.

\section{INTRODUCTION}

Small and medium enterprises (SMEs) in Indonesia have played an essential role in the country's economy (Holy, 2017). According to Bank Indonesia and LPPI (2015) report, SMEs contributed to 90 percent of Indonesia's economic growth. However, due to globalization, Indonesian SMEs face huge challenges since there have been a growing number of import products from other countries, particularly China (cnbcindonesia.com, accessed on August 2019). In dealing with this situation, Indonesian SMEs must improve their competitive advantage and performance to compete with global firms penetrating the Indonesian market.

Previous studies suggested that numerous factors determine SMEs' competitive advantage and performance, but we found several prominent constructs: entrepreneurial orientation, use of information technology, and innovation capabilities. For instance, Kraus et al (2012), Zhang (2012), and Al-Henzab et al. (2018) studies suggested that entrepreneurial orientation positively affects business performance. Van Doorn et al. (2013) stated that the senior team helps companies improve entrepreneurial orientation and improve company performance. While research Cho and Lee (2018) suggested that innovative entrepreneurial orientation indicators influence the performance of non-financial businesses, but indicators of risk-taking do not affect the financial performance of the business non-financial business performance. The research was supported by research Rezaei and Ortt (2018).

Parkman et al. (2012) and Ibrahim and Madichie (2014) found that entrepreneurial orientation on the SMEs positively affects competitive advantage. However, according to Sirivanh et. al. (2014), entrepreneurial orientation has a positive effect but not significant on competitive advantage in the Small and Medium Enterprises (SMEs) in Lao PDR. Chukwunonso et al. (2011), Al-Shbiel and Al-Olimat (2016), Aslizadeh (2014) and Mansouri and Feizi (2015) suggest that the influence of information technology led to the company's competitive advantage. Cakmak et al. (2012) did the contracting company in Turkey is not much evidence to suggest that the use of information technology can improve competitive advantage. The research was supported research conducted Astuti (2017). In their research, Rose et. al. (2010) suggested a positive and significant relationship between organizational resources, competitive advantage, and performance. The research was supported by 
Zainurossalamia et al. (2016) and Jain et al. (2017).

Parkman et al. (2012) showed an important factor for creating a competitive advantage that needs the capability to innovate. Supported research Jose (2012) carried out on an industrial restaurant in Guadalajara, Mexico. Research conducted on SME in Malaysia by Abd Aziz and Samad (2016) showed that $73.5 \%$ innovation contributes to improving competitive advantage. Research of Eidizadeh et al. (2017) shows that positive and significant variables affect organizational innovation to competitive advantage.

In his research, Liao and Wu (2010) suggested that individuals and organizations' performance can be enhanced if it has an innovative organization. Rosli (2013) conducted a study in Malaysia in the Small and Medium Enterprise Manufacturing produce that product innovation and innovation processes significantly affect the company's performance. In addition to consolidating the existing theory about the importance of innovation to explain the variation in the company's performance, these findings also inform SMEs and policymakers that innovation is an important factor in entrepreneurial activity today.

However, to the best of our knowledge, there has been limited evidence from Indonesia that examines the relationship between entrepreneurial orientation, use of information technology, innovation capabilities, competitive advantage, and SMEs' performance. Therefore, we attempted to fill this gap by examining the effect of entrepreneurial orientation, use of information technology, and innovation capabilities on SMEs' competitive advantage and performance.

\section{LITERATURE REVIEW AND HYPOTHESES DEVELOPMENT}

\section{Entrepreneurial orientation and SMEs' performance}

Based on research by Parkman et al. (2012), Bolton and Lane (2012), Kraus et al (2012), Zhang (2012), Al-Henzab et al. (2018) and Van Doorn et al. (2013), increasing entrepreneurial orientation might influence significant positive business performance. While Cho and Lee (2018) found that innovative entrepreneurial orientation indicators affected non-financial businesses' performance, the risk-taking indicator did not affect the business's financial performance and non-financial business performance. Indicators of risk-taking can not affect the production's performance (Rezaei and Ortt, 2018). Based on previous studies mentioned above, this study's first hypothesis is.

H1: Entrepreneurial orientation has a positive effect on SMEs' performance.

\section{Entrepreneurial orientation and SMEs' competitive advantage}

Research conducted Parkman et al. (2012) and Ibrahim and Madichie (2014) revealed that there is a strong relationship between the three-dimension of entrepreneurial orientation (innovation, risk-taking and proactive) on competitive advantage. However, according to Sirivanh et al. in 2014, the entrepreneurial orientation has a positive effect but not significant effect on competitive advantage in the Small and Medium Enterprises (SMEs) in Lao PDR. The second hypothesis that can be constructed in this study are as follows.

H2: Entrepreneurial orientation has a positive effect on SMEs' competitive advantage.

\section{Use of information technology and SMEs' competitive advantage}

Chukwunonso et al. (2011) suggested that information technology led to the company's competitive advantage. The description is following the results of Al-Shbiel and Al-Olimat (2016), Aslizadeh (2014) and Mansouri and Feizi (2015), which has the result that the impact of information technology on competitive advantage. Cakmak et al. (2012) did the contracting company in Turkey is not much evidence to suggest that the use of information technology can improve competitive advantage. Later research by Astuti (2017) resulted in no significant effect between information technology strategy and financial performance. Based on previous research, the third hypothesis can be constructed in this study.

H3: Use of information technology has a positive effect on SMEs' competitive advantage. 


\section{Competitive advantage and SMEs' performance}

Rose et al. (2010), and Zainurossalamia et al. (2016) showed that the concept of organizational excellence according to the resource-based view is very important. It is used as a conceptual guideline in business organizations to improve the position of excellence that distinguishes them from competitors. Performance through manipulation tools and internal resources is also improved by using competency. Excellence can be improved by using these qualities. In their research, Jain et al. (2017) showed that business performance is positively associated with competitive advantage. The fourth hypothesis is built from the description of previous research is as follows:

H4: Competitive advantage has a positive effect on SMEs' performance.

\section{Innovation capability and SMEs' competitive advantage}

Studies conducted by Parkman et al. (2012) and Jose (2012) showed that the better the capability to innovate, the higher the ability to compete. The capability to innovate is essential for creating a competitive advantage. Research conducted on SME in Malaysia by Abd Aziz and Samad (2016) showed that $73.5 \%$ of innovation contributes to competitive advantage changes. This result confirms that innovation elements directly affect the competitive advantage. From a theoretical perspective, a positive and significant effect of the study showed that the greater the innovation, the greater the opportunity for SMEs to gain a competitive advantage. Eidizadeh et al. (2017) found that organizational innovation positively and significantly affects competitive advantage. Based on previous studies explanation mentioned above, we built a fifth hypothesis of this study:

H5: Innovation capability has a positive effect on SMEs' competitive advantage.

\section{Innovation capability and SMEs' performance}

Rosli's (2013) study conducted in Malaysia suggested that SMEs' product innovation and innovation processes significantly affect the company's performance. Dimitrios and Psomas (2013) also had a similar finding. Their research showed that innovation capabilities affect the performance of the business. Furthermore, Liao and Wu (2010) suggested that individuals and organizations' performance can be enhanced if it has an innovative organization. Therefore, we proposed the following hypothesis.

H6: Innovation capability has a positive effect on SMEs' performance.

\section{METHODS}

\section{Procedure of data collection}

Managers or owners of SMEs in Semarang who are members of the Digital Training Class "X" in Semarang were respondents in this study. Researchers conducted data collection by going to digital training classes held every two weeks and distributing questionnaires to the respondents who have been following digital training classes at least one meeting. To complement the hardcopy questionnaire distribution, we distributed online questionnaires using google form through the WhatsApp group of training participants. 86 respondents fill out the hardcopy questionnaire, while 39 respondents fill out the questionnaire via the google form. Thus, the total data collected in this study was 125 respondents.

From the data collected, the majority of respondents were female $(65,6 \%)$ with age category between 20 to 30 years old $(69,6$. The majority of our respondents had a high school education background (76,8\%). According to the business category, 36,8 percent of the respondents were culinary, 31,2 percent were fashion $\%$ and $19,2 \%$ were crafts. Based on the business lifetime, most of the respondents ran their business for 1-2 years $(63,2 \%)$ and had $2-4$ workforce $(53,6 \%)$. Meanwhile, according to their annual turnover, most respondents (44\%) had an annual turnover of between $\mathrm{Rp} 5$ million to $\mathrm{Rp} 10$ million.

\section{Measurements}

In this study, entrepreneurial orientation were measured using five indicators: risk-taking, innovativeness, proactiveness, autonomy, and competitive aggressiveness. Indicators use of information technology used in this 


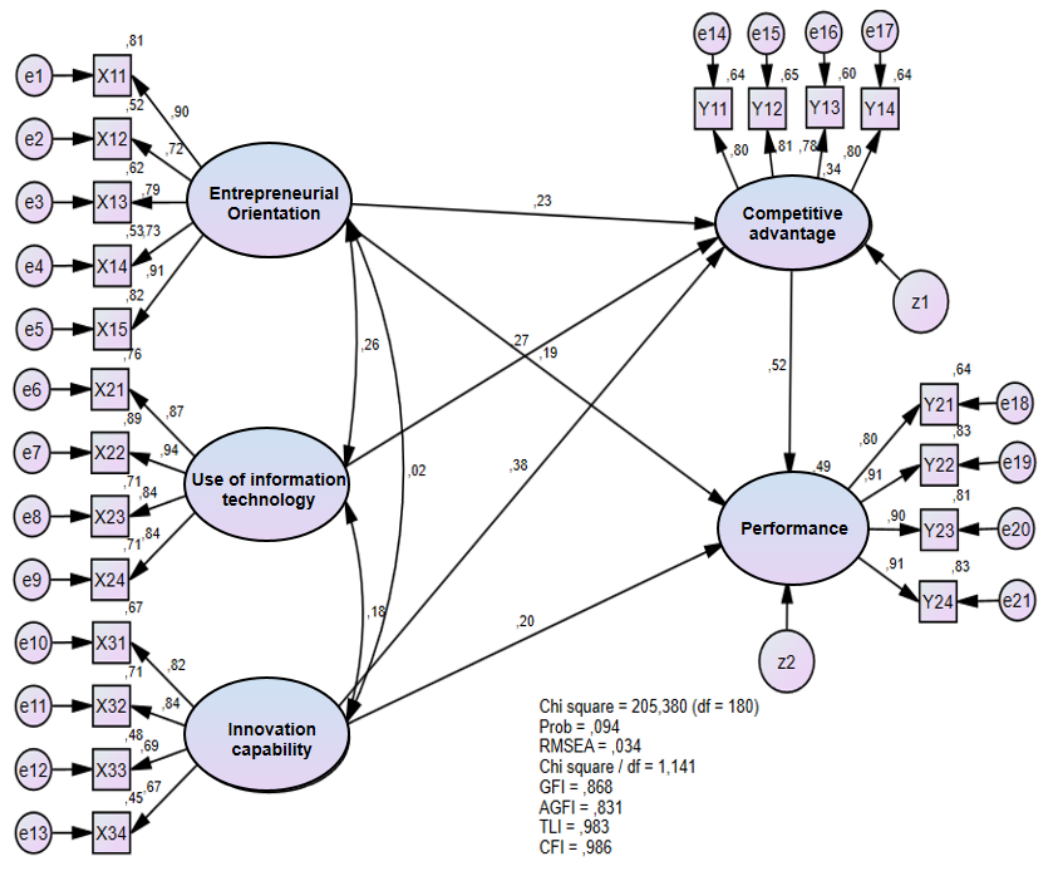

Figure 1.

Results of structural equation model

study are the use of computers, internet use, the use of social media applications, and the competence of the use of information technology. To measure innovation capabilities, we use four indicators: organization innovation capabilities, process innovation capabilities, product innovation capabilities and the marketing innovation capabilities. We used four indicators to measure competitive advantage: competitive prices, superior quality, the uniqueness of the product, the funds are not easily replaced. Meanwhile, to measure SMEs' performance, the indicators used in this study are: the profit growth, subscriber growth, growth of the market, and the growth of assets.

\section{RESULTS AND DISCUSSION}

Once the model is fit, then we performed test of the hypotheses. Figure 3 shows the results of data processing for the full model of SEM analysis. CR value of a causal relationship from the processing of SEM is the basis of this research hypothesis testing. Meanwhile, the Table 1 shows regression weight of structural equational modeling.

\section{Effect of entrepreneurial orientation on SMEs' performance}

The analysis of the effect of entrepreneurial orientation on SMEs' performance as shown in Table 1 suggests that there is a positive direction with the value of $\mathrm{CR}=2.369$ and probability $=0.018$. The significance value is less than 0.05 so it can be interpreted that entrepreneurial orientation positively affects SMEs' performance. Thus, hypothesis 1 is supported.

This results are in line with previous research conducted by Zhang (2012) and

Table 1.

Regression weight of structural equational modeling

\begin{tabular}{rllcccc}
\hline & & & Estimate & S.E. & C.R. & P \\
\hline Competitive advantage & $<---$ & Entrepreneurial orientation & 0.177 & 0.070 & 2.540 & 0.011 \\
Competitive advantage & $<---$ & Use of information technology & 0.234 & 0.080 & 2.921 & 0.003 \\
Competitive advantage & $<---$ & Innovation capability & 0.491 & 0.130 & 3.773 & ${ }_{\star \star \star}$ \\
Performance & $<---$ & Competitive advantage & 0.558 & 0.113 & 4.935 & ${ }^{\star \star \star}$ \\
Performance & $<---$ & Entrepreneurial orientation & 0.159 & 0.067 & 2.369 & 0.018 \\
Performance & $<---$ & Innovation capability & 0.271 & 0.127 & 2.134 & 0.033 \\
\hline
\end{tabular}


Masa'deh et. al. (2018) that found a positive effect from entrepreneurial orientation on the performance of the business. In addition, research conducted Cho and Lee (2018) suggested that innovative entrepreneurial orientation indicators have influence on the performance of non-financial businesses.

\section{The effect of entrepreneurial orientation on SMEs' competitive advantage}

The analysis of the effect of entrepreneurial orientation on SMEs' competitive advantage as shown in Table 1 suggests a positive direction with the value of $C R=2.540$ with probability $=0.011$. The significance value is less than 0.05, which means that entrepreneurial orientation positively affects SMEs' competitive advantage. Thus hypothesis 2 is supported.

This study is consistent with the results of previous studies conducted by Parkman et al. (2012), which suggested that entrepreneurial orientation positively affects competitive advantage. Our finding also confirms Ibrahim and Madichie's (2014) study, which conducted research in Ghana on SMEs and reveals a relationship between entrepreneurial orientation and competitive advantage.

\section{The effect of the use of information technology on SMEs' competitive advantage}

Table 1 also shows that the effect of the use of information technology on SMEs' competitive advantage suggests a positive direction with the value of $\mathrm{CR}=2,921$ and probability $=0.003$. The significance value is less than 0.05 which indicates that the use of information technology positively affects SMEs' competitive advantage. This finding provides supports for hypothesis 3 .

This result is consistent with Chukwunonso et. al. (2011) 's research suggesting that information technology can bring a competitive advantage for companies. The result is also following the results of Al-Shbiel and Al-Olimat (2016), Aslizadeh (2014) and Mansouri and Feizi (2015), which showed that the impact of information technology on competitive advantage is positive.

\section{Effect of SMEs' competitive advantage on SMEs' performance}

Our hypothesis testing, as shown in Table 1 also suggests that competitive advantage has a positive direction to SMEs' performance with the value of $C R=4,935$ and probability $=$ 0.000 . The significance value is less than 0.05 . It indicates that SMEs' competitive advantage has a positive effect on SMEs' performance. It also suggests that the hypothesis 4 is supported.

The results are consistent with Rose et al. (2010), which found a positive and significant relationship between competitive advantage and performance. Our study also agrees with Jain et al. (2017), which suggested that business performance is positively associated with competitive advantage.

\section{The effect of innovation capability on SMEs' competitive advantage}

Table 1 also shows that the effect of innovation capability on SMEs' competitive advantage has a positive direction with the value of $C R=3,773$ and probability $=0.000$. The significance value of less than 0.05 suggests that the innovation capability has a positive effect on competitive advantage. Thus, hypothesis 5 is supported.

Our finding is in line with Abd Aziz and Samad (2016) study, which showed that $73.5 \%$ of innovation contributes to competitive advantage changes. It also confirms a finding from Eidizadeh et al. (2017) who found that organizational innovation positively affects competitive advantage.

\section{The effect of innovation capability on SMEs' performance}

The analysis of the effect of innovation capability on SMEs' performance, as shown in Table 1 suggests a positive direction with the value of $C R=2,134$ and probability $=0.033$. With a significance value of less than 0.05 , it can be concluded that innovation capability has a significant effect on SMEs' performance. Thus, hypothesis 6 is supported.

The results support Liao and Wu (2010) study, which found that organizational performance can be improved by innovating. Our finding is also in line with Rosli (2013), who conducted a study on Malaysian SMEs and found that innovation capability significantly affects their performance. The study also supports research conducted by 
Kafetzopoulos and Psomas (2013), suggesting that innovation capabilities affect the business's performance.

\section{CONCLUSIONS}

The study aims to provide empirical evidence on whether entrepreneurial orientation, use of information technology, and innovation capabilities positively affect SMEs' competitive advantage and performance in the Indonesian context. Our analysis suggests that entrepreneurial orientation, use of information technology, and innovation capability positively affect Indonesian SMEs' competitive advantage and performance.

Our study may provide several managerial implications for SMEs in Indonesia. First, to maximize SMEs' business performance, managers should always look for the opportunities that exist and have higher risk tolerance. Opportunities can be seized by conducting market research to determine market demand.

Second, our finding suggests that SMEs should instill a creative mindset to owners, managers, and employees to create a new idea that has a unique or characteristic compared with competitors to achieve competitive advantage. Also, the competitive attitude of aggressiveness against the competition would make SMEs more robust in the face of competitive threats.

Third, our finding also recommends that the use of information technology may enhance the competitive advantage. The use of information technology is not only done by a company or business that is somewhat large, SMEs can also use information technology in its business activities. It may starts from financial records, a product design, store customer data history, online ordering, and marketing tool products. One of them with the use of social media to introduce the product to potential customers even do transactions. A wide range of social media can be utilized, such as Instagram, Facebook, websites, etc. One of the main social media on the rise is Instagram. The platform effectively informs the products to the customer, especially for the Millennials are currently familiar with social media. In addition, SMEs can use the website as an identity or be called a "digital business cards" for SMEs. The website is listed in the business address, contact, product descriptions, even the customer can place an order through the website. The website will increase the confidence of MSMEs. Compared with SMEs who do not have a website, a customer will prefer SMEs have a website and constantly update the page.

Fourth, the result also shows that competitive advantage positively affects SMEs' performance. The recommendation that may be gained from this finding is SMEs in Indonesia should attempt to create a new product that other competitors do not easily replace, so the customers will not easily switch to competitor products. Moreover, SMEs must maintain the quality of products and services to continue to buy the product and recommend it to their circle. Providing a competitive price can also be used as a business strategy to increase SMEs' performance, as customers will compare prices with other competitors before finally deciding to buy.

Fifth, the finding shows that innovation capabilities positively affects competitive advantage. It implies that to compete with competitors, SMEs need to conduct a training program or sharing sessions with employees to increase knowledge and get ideas or new ideas from employees' viewpoints.

Sixth, our finding also suggests that there are positive effects of innovation capabilities on SMEs' performance. This finding brings implication that the creativity SMEs' owners, the training sessions for the owners and employees, and regularly brainstorm in product development or marketing stratey formulation can improve business performance of SMEs because it may bring SMEs in expanding the market, increasing the number of customers, increase profits and improvement of the business assets.

However, like other studies, our research has a limitation. Since our study uses crosssectional data, our findings only portray conditions in a single moment. Future studies may overcome this drawback by conducting a longitudinal study.

\section{REFERENCES}

Abd Aziz, N. N., \& Samad, S. (2016). Innovation and competitive advantage: Moderating effects of firm age in foods manufacturing SMEs in Malaysia. Procedia Economics and Finance, 35, 256-266.

Al-Henzab, J., Tarhini, A., \& Obeidat, B. Y. (2018). The associations among market orientation, technology orientation, entrepreneurial orientation and organizational performance. Benchmarking: An 
International Journal.Vol.25, 8: 31173142.

Al-Shbiel, S. O., \& Al-Olimat, N. H. (2016). Impact of information technology on competitive advantage in Jordanian commercial banks. Accounting information system effectiveness as a mediating variable. International Journal of Academic Research in Accounting, Finance and Management Sciences, 6(3), 202-211.

Aslizadeh, A. (2014). Impact of using information technology on creating a sustainable competitive advantage for companies;(case study: Golestan food companies). Indian Journal of Fundamental and Applied Life Sciences, 4(54), 1595-1603.

Astuti, E., \& Rahayu, S. M. (2018). The influence of information technology strategy and management support to the internal business process, competitive advantage, financial and non-financial performance of the company. International Journal of Web Information Systems.

Bank Indonesia and LPPI. Business Profile 2015 SMEs.http://www.BI.go.id/id/umkm/penelit ian/nasional/kajian/Documents/Profilpers en20BIsnispersen20UMKM.pdf (04.10.18)

Bolton, D. L., \& Lane, M. D. (2012). Individual entrepreneurial orientation: Development of a measurement instrument. Education+ Training.

Cakmak, P. I., \& Tas, E. (2012). The use of information technology on gaining competitive advantage in Turkish contractor firms. World Applied Sciences Journal, 18(2), 274-285.

Cho, Y. H., \& Lee, J. H. (2018). Entrepreneurial orientation, entrepreneurial education and performance. Asia Pacific Journal of Innovation and Entrepreneurship. Vol.12, 2: 124-134.

Chukwunonso, Franklyn, O Omoju, Joshua Ikani, David and Mohammed Ribadu. (2011). Management of Information Technology for Competitive Advantage: A Case Study Savvy. Department of Information Technology. Federal University of Technology Yola. Vol.1. 121-129.

cnbcindonesia.com, accessed on August 2019. https://www.cnbcindonesia.com/tech/201 90710124813-37-83920/sederet-buktibarang-china-semakin-banjiri-indonesiaraya

Eidizadeh, R., Salehzadeh, R., \& Esfahani, A. C. (2017). Analysing the role of business intelligence, knowledge sharing and organisational innovation on gaining competitive advantage. Journal of Workplace Learning.

Holy, Yuli Rahmini. (2017). Development of MSMEs (micro, small and Medium Enterprises) in Indonesia. Scientific Journal Cano Ekonomo. (Vol. 6 No. 1). STIE Balikpapan. Balikpapan. It 2-57.

Ibrahim, M, and Madichie, (2014). Entrepreneurial orientation among SME manufacturers in Ghana. African Journal of Business and Economic Research, 9 (2/3): 87-115.

Jain, P., Vyas, V., \& Roy, A. (2017). Exploring the mediating role of intellectual capital and competitive advantage on the relation between CSR and financial performance in SMEs. Social Responsibility Journal.

Kafetzopoulos, D., \& Psomas, E. (2015). The impact of innovation capability on the performance of manufacturing companies: The Greek case. Journal of Manufacturing Technology Management., Vol. 26 No. 1, pp. 104-130. https://doi.org/10.1108/JMTM-12-20120117.

Kraus, S., Rigtering, J. C., Hughes, M., \& Hosman, V. (2012). Entrepreneurial orientation and the business performance of SMEs: a quantitative study from the Netherlands. Review of Managerial Science, 6(2), 161182.

Liao, S. H., \& Wu, C. C. (2010). System perspective of knowledge management, organizational learning, and organizational innovation. Expert systems with Applications, 37(2), 1096-1103.

Mansouri, A., \& Feizi, M. (2015). Evacuation the Effect of Information Technology on Competitive Advantage in Ardabil Industrial Zone. Nigerian Chapter of Arabian Journal of Business and Management Review, 62(1891), 1-4.

Parkman, I. D., Holloway, S. S., \& Sebastiao, H. (2012). Creative industries: aligning entrepreneurial orientation and innovation capacity. Journal of research in marketing and entrepreneurship.

Rezaei, J., \& Ortt, R. (2018). Entrepreneurial orientation and firm performance: the mediating role of functional performances. Management Research Review.

Rose, R. C., Abdullah, H., \& Ismad, A. I. (2010). A Review on the Relationship between Organizational Resources, Competitive Advantage and Performance. Journal of International Social Research, 3(11).

Rosli, M. M., \& Sidek, S. (2013). The Impact of innovation on the performance of small and medium manufacturing enterprises:: 
Evidence from Malaysia. Journal of Innovation Management in Small \& Medium Enterprises, 2013, 1.

Sanchez-Gutierrez, J., Gonzalez-Uribe, E. G., Gutierrez-Govea, A., \& Garcia-Jimenez, E. F. (2012). The effects of intellectual capital and innovation on competitiveness: An analysis of the restaurant industry in Guadalajara, Mexico. Journal of Competitiveness Studies, 20(3/4), 32.

Sirivanh, T., Sukkabot, S., \& Sateeraroj, M. (2014). The effect of entrepreneurial orientation and competitive advantage on SMEs' growth: A structural equation modeling study. International Journal of Business and Social Science, 5(6).

Van Doorn, S., Jansen, J. J., Van den Bosch, F. A., \& Volberda, H. W. (2013). Entrepreneurial orientation and firm performance: Drawing attention to the senior team. Journal of Product Innovation Management, 30(5), 821-836.

Zainurossalamia, S., Setyadi, D., \& Rusmilawati, S. (2016). The Effect of Innovation on Firm Performance and Competitive Advantage. European Journal of Business and Management, 8(29), 113-120.

Zhang, Y. (2012). The effect of entrepreneurial orientation on business performance: A role of network capabilities in China. Journal of Chinese Entrepreneurship. 